\title{
Towards the development of learner autonomy of Portuguese mechanical engineering students
}

\author{
Marina Duarte \\ ISEP-P.Porto / CIIE-FPCEUP \\ Polytechnic of Porto / University of Porto \\ Porto, Portugal \\ mic@isep.ipp.pt
}

\begin{abstract}
At the turn of the XXI century, the Bologna Process reinforced the importance of learner autonomy, advocating the adoption of a student-centered paradigm, and placing on the student the responsibility of actively participating in the definition and construction of its educational process. Learner autonomy, as an ability to be responsible for one's own learning and, having this ability, make full use of it, learning in a self-directed manner, has been identified as one of the goals of higher education and as a condition for effective learning. This research aims to identify relationships between learning autonomy and the progression in the studies cycle of Portuguese mechanical engineering students, and by doing so, help to facilitate the adoption of a student-centered learning paradigm. The results show that the development of learner autonomy is not linear and decreases in the $2^{\text {nd }}$ curricular year (studies cycle with three years), meaning that these students will need activities that adequately support their learning.
\end{abstract}

Keywords-self-directed learning, learner autonomy, engineering education

\section{INTRODUCTION}

At the turn of the XXI century, the Bologna Process reinforced the importance of learner autonomy, advocating the adoption of a student-centered paradigm, and placing on the student the responsibility of actively participating in the definition and construction of its educational process. Although the explicit mention of this expected paradigm shift occurred in 2007 [1], Member States felt the need to reinforce it in 2009 [2], to call for its promotion in 2010 [3] and reiterate this commitment in 2012 [4]. More recently, they have taken on their main mission to improve the quality and relevance of learning and teaching by encouraging and supporting Higher Education Institutions (HEI) in promoting pedagogical innovation in student-centered learning environments [5], recognizing in 2018 the need for greater cooperation on innovative teaching and learning practices and committing themselves "to developing new and inclusive approaches to the continuous improvement of learning and teaching" $[6$, p. 3]. The need to move to a more student-centered approach to learning has been very much present in the HEI discourses of the last decade, but the continuing reiteration of the importance of focusing on the students and on learning, and the need for innovative teaching and learning practices [3]-[6], may indicate that the change in the educational paradigm is not yet systematically and uniformly implemented in the European Higher Education Area (EHEA).

In Portugal, a study involving 4972 students from four public universities, concluded that "in all scientific areas, teachers and students have the perception that teaching practices are essentially transmissive" [7, p. 180], indicating that legislative changes and consequent alterations in curriculum plans and their workloads have not yet been sufficient to change the educational paradigm. Another study conducted by Leite [8] with engineering students showed that the most appreciated modes of pedagogical work are lectures supported by visual aids and those that allow the consolidation of knowledge, although participants recognize that higher education, when compared to secondary education, requires greater responsibility, greater autonomy, with less control and monitoring by the teachers.

These results suggest that it is not enough to change legislation and courses, and teachers and their practices if students' relationship with learning remains unchanged and they are not adequately prepared to take responsibility for their learning. Thus, students need to be empowered with learning autonomy, leading them to learn in a self-directed manner and ensuring their ability to manage the workload that is being asked of them, which can easily become too much if their preparation is insufficient, jeopardizing the intended educational paradigm shift.

On the other hand, learner autonomy, as an ability to be responsible for one's own learning and, having this ability, make full use of it, learning in a self-directed manner [9], has been identified by some authors as one of the goals of higher education [10]-[13], and by others as a condition for effective learning [13]-[17]. However, some studies show that learner autonomy does not always improve with the progression of students in higher education, having setbacks in its development [15], [18]-[20], and advances in just a few curricular years [21]-[27].

With this background in mind, it is argued that a better understanding of how learner autonomy develops with the progression in the studies cycle can help facilitate the adoption of a student-centered learning paradigm. Consequently, this research is a case study that aims to identify relationships between learner autonomy and the progression in the studies cycle of Portuguese mechanical engineering students.

\section{LEARNER AUTONOMY IN HIGHER EDUCATION}

\section{A. The importance of the educational context}

Self-directed learning highlights what some authors [28], [29] claim to be the two main components of learner's autonomy: capacity and will. That is: $(i)$ Individuals may be able to make independent choices but do not want to do so for personal reasons; (ii) Individuals may want to make independent choices and not be able to do so. $\mathrm{Hu}$ and Zhang [30] argue that learner autonomy is a variable combination of capacity and will and propose the idea of a learner autonomy continuum composed of four levels: dependence (external regulation), relative dependence (introjected regulation), relative autonomy (identified regulation) and autonomy 
(integrated regulation). From the point of view of regulation, autonomy levels are based on the self-determination continuum by Gagné and Deci [31]. According to $\mathrm{Hu}$ and Zhang [30], when regulation is external, what motivates the action is the intention of obtaining the desired consequence (reward) or avoiding an unwanted (punishment) one. In the introjected regulation, there is already internalization of regulation, but this controls the individual through internal pressures such as guilt and anxiety. The identified regulation is more autonomous than the previous ones. Although the motivation for the action remains external, it is internalized because individuals recognize that the value of behavior is in accordance with their own goals. The complete internalization of regulation takes place in integrated regulation, in which there is coherence between the individuals' behavior, objectives and values and behavior is perceived as an integral part of themselves.

In the autonomy level of the continuum, the students are able to take responsibility for their learning and want to do so, learning in a self-directed way. Self-directed learning is thus the observable behavior of learners' autonomy, but Bouchard [32] claims that its evidence is related not only capacity and will but also opportunity. For the author [32], self-directed learning must involve the interaction of three aspects that relate with capacity, will and opportunity as follows: (1) The application of actions and procedures (which refers to capacity); (2) Correspond to a person who is not psychologically averse to this type of learning (which refers to will); (3) Occur in an environment that at least does not prevent self-directed learning (which refers to a context of formal education that at least provides opportunities).

The importance of the educational context is also recognized by other authors. For Hiemstra and Brockett [33], self-directed learning is more effective when the learner has a high self-direction, the teaching-learning process is configured to encourage students to take responsibility for their own learning, and when the educational context and environment support a self-directed learning climate. Therefore, the responsibility for learning is exercised in an interdependent manner [28], [34] in social learning contexts that should provide opportunities [15] and encourage selfdirected learning. Also, Benson [35], who considers that the exercise of control over learning is a good indicator of autonomy, warns that this is dependent on the opportunities provided by the context, meaning that the absence of manifestations of control may not always indicate lack of ability and willingness to learn in an autonomous way.

Regarding the context in which learner autonomy is exercised, and which allows self-directed learning, emphasis should be placed on valuation, opportunities, and incentives [36]. Although it may seem redundant, valuing autonomy and creating opportunities that allow its exercise may not be enough. Some students may need to be actively encouraged, and it may not be enough to provide an academic context that supports the exercise of autonomy. To believe that this is enough implies that students are already able to recognize the importance of learner autonomy [15], which does not always happen in the transition from high school to higher education. There is evidence that students tend to reproduce the approaches to learning they used previously [37], and that these are inadequate because the "marked discrepancy between High School and Higher Education teaching methodologies and curriculum content... in nothing favors the transition and initial adaptation of students" [38, p. 205].

In face of these difficulties, it is up to the Higher Education Institutions (HEI) to frame and promote a balanced academic context, considering that for new students this is a moment of transition, adjustment of perceptions and expectations, which will require an "increase of autonomy and independence in terms of various aspects, namely at the personal, social and academic level " [39, p. 3505]. Alongside the clear indication of the importance of autonomy, and its deliberate promotion as early as possible [27], through an environment that encourages and values certain pedagogical practices, there must be sufficient space for the most autonomous students to have the freedom needed to chart your own learning path. Although the higher education public is mainly young adults in a situation of economic dependence on their parents, the high number of working students with families and the resulting responsibilities must also be taken into account. This growing adult higher education audience, which despite its maturity is not always autonomous in its learning, also needs to feel supported and oriented, but in a way that does not undermine their independence and goals.

\section{B. Research on learner autonomy development}

In order to assess whether the progression in the studies cycle in higher education promotes learner autonomy, leading students to self-directed learning, several studies have been conducted, with contradictory results. Some authors [15], [18]-[20] report no statistically significant differences in learner autonomy and self-direction in learning as a function of students progression in higher education, while others [19], [21]-[24], [26], [27] report statistically significant relationships between learner autonomy and the curricular year, although limited to a few curriculum years, and with explained variance values of less than $10 \%$.

Regarding these studies (the ones in which statistically significant differences were identified), two types of design stand out: (1) The cross-sectional design, in which distinct groups of students from various curricular years are compared, assuming that as long as the conditions of admission do not change, students entering higher education annually have similar learner autonomy; (2) The longitudinal, in which one or more student groups are followed during their progress in the studies cycle, and their autonomy in learning is measured annually to assess their progress. The most frequent is the cross-sectional design [21]-[24], [26], even though longitudinal studies are more appropriate to obtain more accurate estimates of temporal or post-intervention changes in comparison. Longitudinal studies [25], [27] have higher costs, data collection is more arduous, and maintaining the procedures and commitment of researchers and participants may be more difficult to secure. On the other hand, using the cross-sectional design, it is possible to test the intended effects in a short period, with no problems with the abandonment of the participants. However, as different participants are being tested, the effects of individual variations are not fully controlled [40], which may compromise the discussion of results and conclusions. This leads the authors of these cross-sectional studies [21]-[24], [26] to recommend caution and to suggest additional longitudinal studies. 
Research on the influence of progression in the studies cycle on learner autonomy and self-direction in learning, although not unanimous about the role of higher education, highlight some relevant aspects. Progression in the studies cycle does not always improve learning autonomy and may even slow it down [19], either because: (1) Higher education students already have a higher average self-direction compared with the adult population, that is difficult to increase [21]; (2) Students are asked to learn subjects they have no knowledge of [25]; (3) The development of learner autonomy is not linear, which may lead to periods of stagnation and regression [35]; (4) Learner autonomy evolution is slower than the duration of some studies cycles [27].

When there are improvements in self-direction, they appear to be related to certain curricular years, and possible explanations are advanced in relation to the curricular activities provided by the course and certain curricular units, both positive and negative: if the improvement occurs in final years of the studies cycle, the analysis of the curriculum of the first years shows that they provide a comparatively traditional context, which does not facilitate autonomy [23], [27]; if the improvement occurs in the early years, the existence of open problem curricular units, which promote self-directed learning it is pointed out [22].

\section{METHOD}

\section{A. Research design}

Because the intention of this research was to study the development of learner autonomy of Portuguese undergraduate students (first cycle; 180 credits) by means of exploring with the detail a representative case, the research design was a case study with a cross-sectional design. The choice of cross-sectional design is related to the exploratory character of this study, regarding the possibility of conducting a larger longitudinal study, which would require more resources and time.

For the purpose of this research, the case was a first cycle of studies of a Portuguese Higher Education Institution. The selection of the case was based in several criteria: (1) The scientific area of the studies cycle must require permanent updating, so that learner autonomy is an indispensable competence for its graduates and in the exercise of their profession; (2) The studies cycle should confer professional skills at the end of the first cycle of higher education, as is required by most of the studies cycles in the Bologna framework.

With these criteria in mind, engineering degrees were considered as an appropriate case, because in engineering new fields are constantly emerging [41], which means that the development of learning autonomy skills is crucial to enable lifelong learning and professional updating of engineers. Because Portugal has a binary higher education system [42] (university and polytechnic), the majority of first cycle engineering programs (three years) are ministered in Polytechnic Higher Education Institutions, known as «Superior Institutes of Engineering». Of these Higher Education Institutions, the one in Lisbon (ISEL) and the one in Porto (ISEP) stand out because of their numerical representativeness $(70 \%$ of the polytechnic engineering students, according to the data available in 2010/11, when these research took its first steps [43], [44]). From 2010 to nowadays, ISEP became the Portuguese polytechnic engineering school with the largest number of first cycle students (undergraduate) [45].

Of the ISEP undergraduate studies programs, two stand out for the number of students enrolled and for a steady demand in recent years [46]-[49]. They are the mechanical engineering studies program (LEM) and the computer engineering studies program (LEI, both accredited according to ENAEE standards [50]). Of these, the choice of the case to study fell to LEM, because it has a curriculum with a conventional organization in engineering education (semester curricular units with classes for 16 weeks and possibility of assessment during and after the 16 weeks of classes; a structure with core, engineering science, and specialty curricular units distributed by six semesters; the $6^{\text {th }}$ semester includes an internship or a project work; LEI is organized according to CDIO principles [51]).

\section{B. Participants}

The population for the case study was the 1003 students enrolled in LEM in 2013/14. These students were mostly male $(91.2 \%)$ and Portuguese $(97.8 \%)$. About half of the students $(54.3 \%)$ had ages between 18 and 22 years. The distribution of LEM students between the three curricular years was on average balanced, with $34.2 \%$ students in the $1^{\text {st }}$ year, $34.0 \%$ in the $2^{\text {nd }}$ year and $31.8 \%$ in the $3^{\text {rd }}$ year. The number of graduates was 140 , with an average time of completion of the degree of 4.2 years [46], [48].

The participants were a convenience sample of 425 undergraduate students from the 1003 population of mechanical engineering students enrolled in 2013/14, that agreed to participate in the study. As in the population, the participants were mostly male $(90.4 \%)$ and under 23 years old $(58.4 \%)$. A third of them were $1^{\text {st }}$ year students $(35.1 \%)$, $29.9 \%$ were $2^{\text {nd }}$ students and $34.1 \%$ were in the $3^{\text {rd }}$ year. Some students $(23.3 \%)$ attended classes at night because they worked during the day.

\section{Instruments}

A socio-demographic and academic questionnaire was used to characterize the participants, regarding their age, nationality, gender and curricular year. As an indicator of learner autonomy, the researcher used self-directed learning, measured by the Portuguese adapted version [52] of the Learning Experiences Scale (PRO-SDLS) [53].

The PRO-SDLS was developed by Stockdale and Brockett [53] based on the personal responsibility orientation (PRO) model of self-direction in learning (SDL) by Brockett and Hiemstra [54]. The authors wanted to "empirically validate new ways of studying self-direction that are informed by more recent conceptualizations of selfdirection" [53, p. 162] and to "develop a reliable and valid instrument to measure self-directedness in learning among college students" [53, p. 167].

Stockdale and Brockett's operationalization of the PROSDL model [53] identifies four dimensions of paramount importance for the development of learner autonomy: control, initiative, motivation, and self-efficacy. Thus, the perceptions of students who are more predisposed to selfdirected learning should demonstrate proactivity in controlling and initiating the planning, implementation and 
evaluation of the learning process, as well as motivation to act autonomously and confidence to do so.

The PRO-SDLS is based on a five-point Likert type format that was found suitable to "best reflect student's degree of agreement or disagreement with statements pertaining to self-perceptions of their actions and beliefs in self-directed learning opportunities" [53, p. 167], and has a total of 25 items (control, initiative, and self-efficacy has six items each and motivation has seven) for a maximum score of 125 points obtained after reversing negative items and summing up all scores.

The Portuguese adapted version [52] of the Learning Experiences Scale (PRO-SDLS) keeps the factors structure of the original version, with a total of 12 items (three items for each of the four dimensions. The total score is also obtained by the sum of all items of the PRO-SDLS after negative items were reversed, for a maximum score of 60 points [52].

\section{Procedures}

Before data collection, approval for the study was obtained from the President of ISEP. In March 2014, the researcher approached students during classes (with the permission and cooperation of their teachers) and asked them to answer to the paper-and-pen questionnaires. The purpose of the study was explained to participants by the researcher. They were also informed that the data collection was completely anonymous, voluntary and confidential and that returning the completed questionnaires would be interpreted as informed consent. Students not wishing to participate in the study were told that it would be enough to return a blank questionnaire.

To assess the effect of the curricular year on self-directed learning, the possibility of attending classes during the day or at night was considered. Thus, a two-way factorial ANOVA was used to determine whether the factor curricular year and the factor schedule of class attendance influenced the selfdirection in learning. Since one of the factors could have three distinct values $\left(1^{\text {st }}\right.$ year, $2^{\text {nd }}$ year and $3^{\text {rd }}$ year $)$, posthoc tests (Tukey test) were also performed to identify which groups had significantly different means.

The ANOVA assumptions of the normality of the dependent variable, and of homogeneity of populational variances were all verified with the Kolmogorov-Smirnov test and Levene test, as suggested by Marôco [55]. The sample size was also taken into consideration, verifying that the minimum case size in the study sample for three-level factors was at least 80 cases, with a minimum number of cases in each subgroup of 27 as suggested by Pestana and Gageiro [56]. To address the issue of large samples, because they "can lead to statistically significant results... even if the differences between groups are small" [55, p. 248], Marôco [55] recommendation of evaluation the effect size was followed, resorting to Ferguson [57] indication of the measures eta square and partial eta squared as the most commonly used in factorial ANOVA. Espirito-Santo and Daniel [58] suggest interpreting these measures regarding small, medium and large effects based on the limit values of $0.0099,0.0588$ and 0.1379 , respectively, which were the criteria adopted in this research.

\section{RESUlts}

Regarding the measurement of self-directed learning with the Portuguese adapted version of PRO-SDLS, results show that the participants have a self-directed learning average of 41.63 points in $60(\mathrm{SD}=5.546)$, which represents $69.4 \%$ of the maximum score, with $50 \%$ of the participants scoring between 38 and 45 points, as shown in Figure 1 (that is, between $63.3 \%$ and $75.0 \%$ of the maximum score).

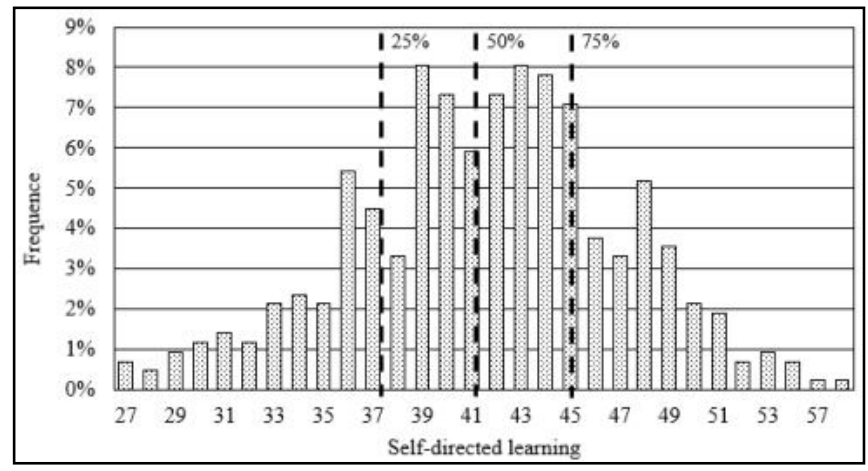

Fig. 1. Self-directed learning (average) of students per curricular year

Of the factors considered, only the curricular year has a statistically significant effect on self-directed learning, but the effect size is small $(Z(5,413)=4.324 ; p=0.014$; partial eta square $=0.021$; power $=0.750)$. The participants of the $2^{\text {nd }}$ year are those with the lowest self-directed learning $(\mathrm{M}=40.3 ; \mathrm{SD}=5.298 ; \mathrm{N}=127)$, followed by the $1^{\text {st }}$ year $(\mathrm{M}=41.5 ; \mathrm{SD}=5.731 ; \mathrm{N}=149)$ and $3^{\text {rd }}$ year $(\mathrm{M}=42.9$; $\mathrm{SD}=5.313 ; \mathrm{N}=145)$, as shown in Figure 2. According to Tukey's posthoc test, statistically significant differences in self-directed learning for the curricular year factor occur between the $2^{\text {nd }}$ year and the $3^{\text {rd }}$ year (confidence interval at $95 \%$ ]-4.13; $-1.00[; \mathrm{p}=0.000)$.

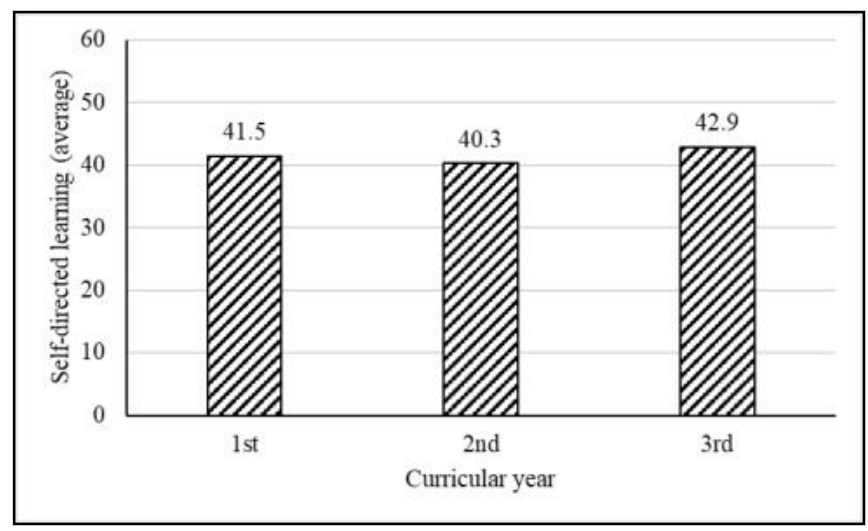

Fig. 2. Self-directed learning (average) of students per curricular year

\section{DISCUSSION AND CONCLUSION}

Most participants in this study perceive their learning as moderately self-directed according to the measured values with the adapted version of PRO-SDLS. This result is similar to the $67 \%$ reported in the validation of the PROSDLS [53] and it is in agreement with other studies using the same scale, that report values between $67 \%$ and $75 \%$ [59]-[61]. 
These moderate levels of self-directed learning, identified in most participants, corresponding to the levels of autonomy of relative dependence and relative autonomy [30], [31], indicating that these students are not totally dependent on teaching for their learning, but still need the presence and intervention of the teacher [10].

As for the pattern of variation of self-directed learning, the results indicate a decrease from the $1^{\text {st }}$ year to the $2^{\text {nd }}$ year, and an increase from the $2^{\text {nd }}$ year to the $3^{\text {rd }}$ year, compatible with the developmental nature of learner autonomy and its non-linear progression and periods of stagnation and regression [35], according to the demands and challenges placed on students' learning.

Knowledge of the levels of the participants' learner autonomy and its development pattern indicates what is the curricular year in which they need more activities that adequately support their learning. This can constitute an important tool for teachers and Higher Education Institutions when designing and planning studies programs capable of promoting the development of learner autonomy.

The fact that the participants of the $3^{\text {rd }}$ year are the one that perceive themselves as learning in a more self-directed, even though with a small effect size that is compatible with the idea that learner autonomy evolution is slow [27], indicates an academic context in students are challenged and face difficulties $\left(2^{\text {nd }}\right.$ year), but also where valuation, opportunities, and incentives are present ( $3^{\text {rd }}$ year). Because this is a case study with a cross-sectional design, these conclusions should be interpreted with caution, but are a good indicator that a large-scale longitudinal study would be useful and recommended.

\section{ACKNOWLEDGMENT}

Doctor Susan Stockdale for sharing the English version of the PRO-SDLS scale and allowing its adaption for Portuguese.

Doctor Carlinda Leite and Doctor Ana Mouraz for all the support and supervision of my $\mathrm{PhD}$ on Learner Autonomy and Workload of Portuguese Mechanical Engineering Students, concluded in 2019.

\section{REFERENCES}

[1] European Ministerial Conference, 'London Communiqué', 2007.

[2] European Ministerial Conference, 'Leuven and Louvain-la-Neuve Communiqué', 2009.

[3] European Ministerial Conference, 'Budapest-Vienna Declaration', 2010.

[4] European Ministerial Conference, 'Bucharest Communiqué', 2012.

[5] European Ministerial Conference, 'Yerevan Communiqué', 2015.

[6] European Ministerial Conference, 'Paris Communiqué', 2018.

[7] A. Borralho, I. Fialho, M. Cid, P. Alves, and J. C. Morgado, 'Práticas Curriculares nas universidades portuguesas: estudo comparativo para as diferentes áreas do conhecimento', in Avaliação, Ensino e Aprendizagem no Ensino Superior em Portugal e no Brasil: Realidades e Perspectivas, vol. 1, D. Fernandes, A. Borralho, C. Barreira, A. Monteiro, D. Catani, E. Cunha, and M. P. Alves, Eds. Lisboa: Educa, 2014, pp. 137-184.

[8] C. Leite, 'Questões do currículo no ensino universitário: o que distingue a organização e o desenvolvimento do currículo deste nível de ensino?', in Políticas, fundamentos e práticas do currículo, C. Leite, J. A. Pacheco, A. F. B. Moreira, and A. Mouraz, Eds. Porto: Porto Editora, 2011, pp. 278-287.

[9] H. Holec, Autonomie et apprentissages des langues étrangères. Strasburgo: Conseil de L'Europe, 1979.
[10] D. Boud, 'Moving towards autonomy', in Developing student autonomy in learning, D. Boud, Ed. London: Kogan Page, 1988, pp. $17-39$.

[11] V.-M. D'Andrea and D. Gosling, Improving teaching and learning in higher education: a whole institution approach. Nova Iorque: SRHE \& Open University Press, 2005.

[12] M. Zabalza, Uma nova didáctica para o ensino universitário: respondendo ao desafio do espaço europeu de ensino superior. Porto: Universidade do Porto, 2006.

[13] J. Rué, El Aprendizaje Autónomo En Educación Superior. Madrid: Narcea, 2009.

[14] D. Boud, 'Introduction to the second edition', in Developing student autonomy in learning, D. Boud, Ed. London: Kogan Page, 1988, pp. $7-16$.

[15] D. C. Henri, L. J. Morrell, and G. W. Scott, 'Student perceptions of their autonomy at University', High. Educ., vol. 75, no. 3, pp. 507516, Mar. 2018

[16] A. G. Holmes, 'Problems With Assessing Student Autonomy in Higher Education, an Alternative Perspective and a Role For Mentoring', Educ. Process Int. J., vol. 7, no. 1, pp. 24-38, 2018.

[17] D. Little, Learner Autonomy 1: Definitions, Issues and Problems. Dublin: Authentik, 1991.

[18] T. Litzinger, J. Wise, S. Lee, and S. Bjorklund, 'Assessing Readiness for Self-directed Learning', in Proceedings of the 2003 American Society for Engineering Education Conference, 2003.

[19] K. Premkumar et al., 'Self-directed learning readiness of Indian medical students: a mixed method study', BMC Med. Educ., vol. 18, no. 1, p. 134, Dec. 2018.

[20] G. W. Scott, J. Furnell, C. Murphy, and R. Goulder, 'Switching on the skills for lifelong learning: revision of programmes and modules to enhance the development of learning autonomy (final report)', 2011.

[21] B. J. Harvey, A. I. Rothman, and R. C. Frecker, 'Effect of an Undergraduate Medical Curriculum on Students' Self-Directed Learning', Acad. Med., vol. 78, no. 12, pp. 1259-1265, 2003.

[22] T. Litzinger, J. Wise, and S. Lee, 'Self-directed Learning Readiness Among Engineering Undergraduate Students', J. Eng. Educ., vol. 94, no. 2, pp. 215-221, 2005.

[23] A. Oliveira, 'Aprendizagem autodirigida: Um contributo para a qualidade do ensino superior (tese de doutoramento)', Faculdade de Psicologia e Ciências da Educação da Universidade de Coimbra, Coimbra, 2005.

[24] M. K. Ponton and P. B. Carr, 'The possible role of higher education in developing learner autonomy: A quantitative exploration', Int. J. SelfDirected Learn., vol. 13, no. 1, pp. 12-25, 2016.

[25] K. Premkumar, P. Pahwa, A. Banerjee, K. Baptiste, H. Bhatt, and H. J. Lim, 'Does Medical Training Promote or Deter Self-Directed Learning? A Longitudinal Mixed-Methods Study', Acad. Med., vol. 88, no. 11, pp. 1754-1764, Nov. 2013.

[26] G. W. Scott, J. Furnell, C. Murphy, and R. Goulder, 'Teacher and student perceptions of the development of learner autonomy; a case study in the biological sciences', Stud. High. Educ., vol. 40, no. 6, pp. 945-956, 2015.

[27] A. Oliveira, 'A autonomia na aprendizagem no ensino superior: reflexões a partir de dados transversais e longitudinais', in Avaliação, Ensino e Aprendizagem no Ensino Superior em Portugal e no Brasil: Realidades e Perspectivas, vol. 2, D. Fernandes, A. Borralho, C. Barreira, A. Monteiro, D. Catani, E. Cunha, and M. P. Alves, Eds. Lisboa: Educa, 2014, pp. 791-812.

[28] J. Higgs, 'Planning learning experiences to promote autonomous learning', in Developing student autonomy in learning, D. Boud, Ed. Kogan Page, 1988, pp. 40-58.

[29] W. Littlewood, “Autonomy": An anatomy and a framework', System, vol. 24, no. 4, pp. 427-435, 1996.

[30] P. Hu and J. Zhang, 'A pathway to learner autonomy: a selfdetermination theory perspective', Asia Pacific Educ. Rev., vol. 18, no. 1, pp. 147-157, Mar. 2017.

[31] M. Gagné and E. L. Deci, 'Self-determination theory and work motivation', J. Organ. Behav., vol. 26, pp. 331-362, 2005.

[32] P. Bouchard, 'Self-directed learning and learner autonomy', in The Encyclopedia of the sciences of learning, S. Norbert, Ed. New York: Springer Science and Business Media, 2011. 
[33] R. Hiemstra and R. G. Brockett, 'Reframing the Meaning of SelfDirected Learning: An Updated Model', in Adult Education Research Conference Proceedings, 2012.

[34] D. Ciechanowska, 'The contemporary university as a threat to learner autonomy', in Education of Tomorrow: Education and Other Forms of Activity of Adults, Sosnowiec, 2015.

[35] P. Benson, Teaching and researching autonomy in language learning. Harlow: Longman/Pearson Education, 2001.

[36] M. Duarte, 'Processo de Bolonha, autonomia na aprendizagem e carga de trabalho: um estudo com estudantes de engenharia (Doctoral Thesis)', Universidade do Porto, 2019.

[37] H. Lowe and A. Cook, 'Mind the Gap: Are students prepared for higher education?', J. Furth. High. Educ., vol. 27, no. 1, pp. 53-76, 2003.

[38] H. C. Freitas, N. Raposo, and L. S. Almeida, 'Adaptação do estudante ao ensino superior e rendimento académico: Um estudo com estudantes do primeiro ano de enfermagem', Rev. Port. Pedagog., vol. 41, no. 1, pp. 179-188, 2007.

[39] S. Monteiro, R. Vasconcelos, and L. S. Almeida, 'Rendimento académico : influência dos métodos de estudo', in Actas do Congresso Galaico-Português de Psicopedagogia, 2005, pp. 3505-3516.

[40] M. M. P. E. da Mota, 'Metodologia de Pesquisa em Desenvolvimento Humano: Velhas Questões Revisitadas', Rev. Psicol. em Pesqui., vol. 4, no. 2, pp. 144-149, 2010.

[41] D. Dutta, L. Patil, and J. B. P. Jr, Lifelong Learning Imperative in Engineering: Sustaining American Competitiveness in the 21st Century. Washington, DC: National Academies Press, 2012.

[42] Assembleia da República, 'Lei n.o 62/2007', Diário da República, vol. 1.a Série, no. N.o 174, pp. 6358-6389, 2007.

[43] Instituto Superior de Engenharia de Lisboa, 'Relatório de Actividades e Contas relativamente ao ano de 2010', Lisboa, 2011.

[44] Instituto Superior de Engenharia do Porto, 'Relatório de Atividades do ano 2010', Porto, 2011.

[45] Direção-Geral de Estatísticas da Educação e Ciência, 'Tabelas de dados do Ensino Superior'. [Online]. Available: http://www.dgeec.mec.pt/np4/235/. [Accessed: 14-Jan-2019].

[46] Instituto Superior de Engenharia do Porto, 'Relatório de Atividades do ano 2013', Porto, 2014.

[47] Instituto Superior de Engenharia do Porto, 'Relatório de Atividades do ano 2015', Porto, 2016.

[48] Instituto Superior de Engenharia do Porto, 'Relatório de Atividades do ano 2014', Porto, 2015.

[49] Instituto Superior de Engenharia do Porto, 'Relatório de Atividades do ano 2016', Porto, 2017.

[50] European Network for Engineering Acreditation, 'EUR-ACE Framework Standards and Guidelines', 2015.

[51] CDIO Initiative, 'CDIO Map'. [Online]. Available: http://www.cdio.org/node/5927. [Accessed: 14-Jan-2019].

[52] M. Duarte, 'Learner Autonomy of Engineering Students: Validating the PRO-SDLS scale in a Portuguese context', Int. J. Eng. Pedagog., vol. 4, no. 5, pp. 62-67, Mar. 2014.

[53] S. L. Stockdale and R. G. Brockett, 'Development of the PRO-SDLS: A Measure of Self-Direction in Learning Based on the Personal Responsibility Orientation Model', Adult Educ. Q., vol. 61, no. 2, pp. 161-180, May 2011.

[54] R. G. Brockett and R. Hiemstra, Self-direction in learning: Perspectives on theory, research, and practice. New York: Routledge, 1991.

[55] J. Marôco, Análise Estatística com o SPSS Statistics. Pero Pinheiro: Report Number, 2011.

[56] M. H. Pestana and J. N. Gageiro, Análise de Dados para Ciências Sociais: a complementaridade do SPSS. Lisboa: Edições Sílabo, 2008.

[57] C. Ferguson, 'An effect size primer: A guide for clinicians and researchers', Prof. Psychol. Res. Pract., vol. 40, no. 5, pp. 532-538, 2009.

[58] H. M. A. Espirito-Santo and F. Daniel, 'Calcular e apresentar tamanhos do efeito em trabalhos científicos (3) Guia para reportar os tamanhos do efeito para análises de regressão e ANOVAs', Rev. Port. Investig. Comport. e Soc., vol. 4, no. 1, pp. 43-60, 2018.
[59] J. Beard, 'Self-Directed Learning: A Potential Predictor of Technology Integration Confidence among Preservice Teachers (Doctoral Thesis)', University of Tennessee, Knoxville, 2016.

[60] J. Hall, 'Self-Directed Learning Characteristics of First-Generation, First-Year College Students Participating in a Summer Bridge Program (Doctoral Dissertation)', University of South Florida, Tampa, 2011.

[61] L. L. Holt, 'Self-direction and Technology Use Among New Workforce Entrants (Doctoral Thesis)', University of Tennessee, Knoxville, 2011. 